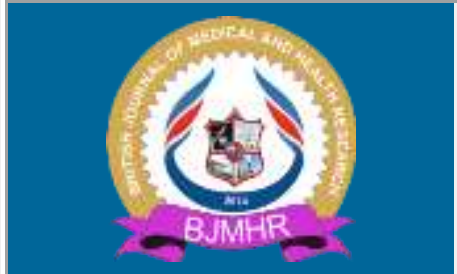

\title{
BJMHR
}

British Journal of Medical and Health Research Journal home page: www.bjmhr.com

\section{Red cabbage and broccoli (Brassica oleracea) extracts inhibits cell proliferation by inducing apoptosis in colorectal cell lines}

Karim Samy El-Said ${ }^{1}$, Maisa Mohamed Abd Elhamid ${ }^{1}$, El-Refaie Kenawy ${ }^{2}$

1.Biochemistry Division, Chemistry Department, Faculty of Science, Tanta University, Egypt

2. Chemistry Department, Faculty of Science, Tanta University, Egypt

\section{ABSTRACT}

Plants-derived chemical constituents have been potentially used in cancers therapy, which are safer than chemotherapy. Apoptosis is a cellular process of defined programmed cell death that is of tremendous interest to study and treat cancer. In the present study, the antioxidants activities of red cabbage leaves and broccoli florets (Brassica vegetables) extracts and their apoptotic effects on colorectal cancer cell lines $(\mathrm{CaCO} 2)$ were investigated. Antioxidants properties of the aqueous methanolic extracts were addressed through determining total phenolics, flavonoids, total antioxidant capacities and DPPH scavenging activities. Then, anticancer properties were assessed by determining the inhibitory concentrations that kill $50 \%$ of $\mathrm{CaCO} 2$ using MTT assay. To investigate the apoptotic effects of the extracts, gene expression analysis using real time polymerase chain reaction (RT-PCR) of Bax, caspase 3 and $\mathrm{Bcl}_{2}$ genes was done. The results showed that red cabbage and broccoli extracts exhibited powerful antioxidant activities. Furthermore, these extracts induce apoptosis in $\mathrm{CaCO} 2$ cells by upregulating Bax and caspase 3 and downregulating $\mathrm{Bcl}_{2}$ genes. In conclusion, red cabbage extract showed strong antioxidant activities more than broccoli extract, while broccoli inhibit proliferation of colon cancer cells by promoting apoptosis more than red cabbage done. Cruciferous vegetables contain important substances targeting apoptosis in $\mathrm{CaCO} 2$ cell lines that can significantly inhibit colon cancer growth.

Keywords: Red cabbage, Broccoli, Colorectal cell lines, Antioxidants, Anticancer, Apoptosis.

Please cite this article as: Karim SE et al., Red cabbage and broccoli (Brassica oleracea) extracts inhibits cell proliferation by inducing apoptosis in colorectal cell lines. British Journal of Medical and Health Research 2019. 


\section{INTRODUCTION}

Phytochemicals are crucial for health care and potentially used in the treatment of numerous diseases including cancer, inflammation, cardiovascular and neurodegenerative disorders $\left[{ }^{1}\right]$. Phenolic compounds are plants secondary metabolites include phenols, flavonoids, lignins, tannins, xanthones, and coumarins have been used in pharmaceutical studies with high impact cancer treatment and harmful diseases $\left.{ }^{2,3}\right]$. The health beneficial effects of dietary phenols are due to their ability to exhibit antioxidant, anti-inflammatory and anti-clastogenic activities. Anti-carcinogenic effects of phenolics could be due to the ability to: cell cycle arrest induction; oncogenic signaling, and angiogenesis inhibition; apoptosis induction; modulate ROS levels; and/or tumor suppressor proteins promotion $\left[{ }^{4}\right]$.

Plants belonging to the family of Brassicas are known for their rich bioactive composition as phenolics, flavonoids and glucosinolates with promising antioxidant and anticancer activities $\left.{ }^{5}\right]$. It has been reported that brassica vegetable intakes causes a very low risk of chronic diseases such as cardiovascular disease and cancer $\left[{ }^{6}\right]$. Broccoli (Brassica Oleracea Italica) is one of known nutritionally important crop that has organo-sulfur compounds help in detoxification of carcinogens $\left[{ }^{7}\right]$. Red cabbage (Brassica Oleracea Capitata Rubra) is one of known popular vegetables which are rich in minerals, vitamins, antioxidant substances and anthocyanins that are beneficial to human body $\left[{ }^{8}\right]$.

Apoptotic abnormalities encompass in the pathogenesis of colorectal cancer and chemotherapeutic resistance. Food constituents including flavonoids, butyrate, glucosinate and brassicas breakdown products are known to prevent colorectal cancer development by enhancing apoptosis following DNA damage that could help in understanding the molecular mechanism of cancer prevention $\left[{ }^{9-12}\right]$.

In the present study, the antioxidants activities of red cabbage and broccoli (Brassica oleracea) extracts as well as the molecular mechanism by which these extracts could promote apoptosis in human colorectal cancer cell lines was investigated through analyzing apoptotic related genes expression that help in development of therapeutic strategies using natural products extracts designed to target apoptosis.

\section{MATERIALS AND METHOD}

Plant materials and extraction: Brassica oleracea vegetables plants, red cabbage leaves and broccoli florets were collected from the Carfour hyper in Tanta City, Egypt. The plant materials were identified and authenticated by classification for species Brassica oleracea. Plants database, United States Department of Agriculture. Leaves and florets parts were dried and grounded then $50 \mathrm{~g}$ were extracted in $400 \mathrm{~mL}$ of $70 \%$ ethanol. Samples were centrifuged and the supernatant was used for the assessment of antioxidants and anticancer properties. Total 
phenolics of the extracts were determined using the Folin-Ciocalteau reagent. The extract solutions $(100 \mu \mathrm{L})$ were mixed with $1 \mathrm{~mL}$ diluted Folin-Ciocalteau reagent, $1 \mathrm{~mL}$ sodium bicarbonate solution $(7.5 \%$ ), and $1 \mathrm{~mL}$ distilled water. The absorbance was determined at 730 nm after 15 min., using agallic acid equivalents (GAE) calibration curve. The total phenolic content was expressed as milligrams gallic acid equivalents per gram of extracts $\left[{ }^{13}\right]$. Total flavonoids were determined using the aluminium chloride colorimetric method using quercetin as a standard and expressed $(\mathrm{mg})$ as quercetin equivalent per gram of extract $\left[{ }^{14}\right]$. Briefly, 0.5 $\mathrm{mL}$ of extracts samples solution in methanol was mixed with $2 \mathrm{~mL}$ of distilled water and 150 $\mu \mathrm{l}$ of $5 \%$ sodium nitrate. After $6 \mathrm{~min}, 150 \mu \mathrm{L}$ of $10 \%$ aluminum chloride and $2 \mathrm{~mL}$ of sodium hydroxide $(1 \mathrm{M})$ were added. Absorbance was measured at $510 \mathrm{~nm}$ after $15 \mathrm{~min}$., and total flavonoid contents were calculated as mg quercetin equivalents from a calibration curve of quercetin. Phosphomolybednum method was used to determine the total antioxidant capacities of the two extracts $\left[{ }^{15}\right]$. The antioxidant capacity was expressed as ascorbic acid equivalent. Briefly, $100 \mu \mathrm{L}$ of hydro-alcoholic extracts were added to $3 \mathrm{~mL}$ of distilled water and $1 \mathrm{~mL}$ of molybdate reagent solution, incubated at $95{ }^{\circ} \mathrm{C}$ for $90 \mathrm{~min}$, then cooled and the absorbance was measured at $695 \mathrm{~nm}$. Ascorbic acid was used as positive reference standard. Crude extracts were used for evaluating the free radical scavenging capacity spectrophotometrically $\left[{ }^{16}\right]$. Briefly, $2 \mathrm{~mL}$ of freshly prepared methanol solution of DPPH $(0.0025 \%)$ was added to $100 \mu \mathrm{L}$ of extracts and allowed to stand at room temperature for $30 \mathrm{~min}$. The absorbance of sample solution $\left(\mathrm{A}_{\mathrm{s}}\right)$ was measured at $517 \mathrm{~nm}$, compared with that of control solution $\left(\mathrm{A}_{\mathrm{c}}\right)$. Control solution was prepared containing the same volume without any extract. The scavenging activity on the DPPH radical was expressed as inhibition percentage using the following equation: Radical scavenging activity $\%=\left[\left(\mathrm{A}_{\mathrm{C}}-\mathrm{A}_{\mathrm{S}}\right) /\left(\mathrm{A}_{\mathrm{C}}\right)\right] \times 100$.

The human colorectal cancer cell line $\mathrm{CaCo} 2$ cells were obtained from the American Type Culture Collection (ATCC, Manassas, Virginia, USA). Cells were transferred to DMEM medium (GIBCO, New York, USA) supplemented with $10 \%$ heat-inactivated fetal bovine serum, $1 \%$ penicillin/streptomycin and $2 \%$ L-glutamine and centrifuged at $1500 \mathrm{rpm}$ for 5 minutes. Cell pellets were re-suspended in culture medium and cultured at $37^{\circ} \mathrm{C}$ for 3 days under $5 \% \mathrm{CO}_{2}, 95 \%$ air for stabilization. Culture renewal was done when the cells reached 8090\% confluence for 5 days. For splitting, the medium was aspirated and the cells were washed with sterile PBS (pH 7.4) for three times. PBS was removed and $0.025 \%$ trypsin-EDTA was added to the flasks. Flasks were incubated in the incubator for 3-5 minutes until the cells were detached. Cells were cultured in the desired dilution into new flasks.

The MTT assay protocol was used to check the cytotoxic effects of the extracts on $\mathrm{CaCO} 2$ cells. On the day of the viability assay, the medium was removed and fresh medium was added. 
The plants extracts were diluted with saline to different concentrations (from 100 to 3.125 $\mu \mathrm{g} / \mathrm{mL}$ ) and applied in triplicate to the $\mathrm{CaCO} 2$ cells (at 70-80\% confluent), incubated at $37{ }^{\circ} \mathrm{C}$ and $5 \% \mathrm{CO}_{2}$ for $24 \mathrm{H}$; then, $10 \mu \mathrm{L}$ of 3-(4,5-dimethylthiazol-2-yl)-2,5-diphenyl-terazolium bromide (MTT) solution [5 mg/ml in phosphate-buffered-saline (PBS)] was added to each well. This was followed by incubation for $4 \mathrm{~h}$ at $37{ }^{\circ} \mathrm{C}$. The MTT solution was removed, and the purple formazan crystal formed at the bottom of the wells was dissolved with $100 \mu \mathrm{L}$ of DMSO for $20 \mathrm{~min}$. Tamoxifen (Tam) was used as a positive standard. The absorbance at $570 \mathrm{~nm}$ was read on ELIZA reader (StatFax-2100, Awareness Technology, Inc.).

To quantify the concentration of RNA and cDNA to be sure that the concentrations are pure enough to conduct real time PCR, the absorption of Ultra-Violet (UV) light by the ring structure of purines and pyrimidines can be used to measure the amount of nucleic acids. The Q5000 (Uv-Vis spectrophotometer Q5000/USA) automatically performs all necessary measurements and calculations. The upper arm of instrument was left and $1.5 \mu \mathrm{L}$ of blank buffer was first used to the lower surface to get the blank reading $1.5 \mu \mathrm{L}$ of sample was measured by the same method. The absorbance of the sample was read at 260 and $280 \mathrm{~nm}$ wavelength. The concentration based on an optic density (OD) of 1 corresponding to approximately $50 \mu \mathrm{g} / \mathrm{mL}$ for RNA was then automatically calculated. The OD260/OD280 ratio for pure RNA is $\geq 2$. Contamination by protein (which has an absorbance maximum of $280 \mathrm{~nm}$ ) or phenol will cause the ratio to be significantly lower than these values.

The total RNA was extracted from the $\mathrm{CaCO} 2$ cells with an RNeasy Mini kit according to the manufacturer's protocol. After the determination of the RNA purity and concentration, complementary DNA was synthesized from $4 \mu \mathrm{g}$ of the total RNA (per sample) with Quant script reverse transcriptase. The isolated complementary DNA was amplified with 2X Maxima SYBR Green/ROX qPCR Master Mix according to the manufacturer's protocol (Thermo Scientific, \# K0221) and gene-specific primers as shown in table 1. The reaction volume and qPCR thermal conditions were applied. At the end of the last cycle, the temperature was increased from 60 to $95{ }^{\circ} \mathrm{C}$ to produce a melt curve. The relative change in gene expression was represented as fold change with critical threshold quantities and the $2^{-\Delta \Delta C t}$ method $\left[{ }^{17}\right]$.

Table 1: Forward and reverse primers sequence for candidate genes.

\begin{tabular}{|c|c|c|c|}
\hline Gene & $\begin{array}{l}\text { Forward primer } \\
(/ 5 \text {-.-- } / 3)\end{array}$ & $\begin{array}{l}\text { Reverse primer } \\
(/ 5 \text {---./3) }\end{array}$ & $\begin{array}{l}\text { Accession } \\
\text { number }\end{array}$ \\
\hline Bax & TGCTTCAGGGTTTCATCCAG & GGCGGCAATCATCCTCTG & NM_001291428 \\
\hline Caspas & TTAATAAAGGTATCCATGGAGA & TTAGTGATAAAAA & NM_032991.2 \\
\hline e3 & ACACT & TAGAGTTCTTTTGTGAG & \\
\hline$B c l 2$ & $\begin{array}{l}\text { AGGAAGTGAACATTTCGGTGA } \\
\text { C }\end{array}$ & $\begin{array}{l}\text { GCTCAGTTCCAGGACCAG } \\
\text { GC }\end{array}$ & NM_000633 \\
\hline $\begin{array}{l}\text { GAPD } \\
H\end{array}$ & TGCACCACCAACTGCTTAGC & $\begin{array}{l}\text { GGCATGGACTGTGGTCAT } \\
\text { GAG }\end{array}$ & NM_002046 \\
\hline
\end{tabular}


Numerical data obtained from each experiment were expressed as mean \pm S.D. Statistical differences between the experimental groups were assessed using one-way ANOVA, $p$ Values less than 0.05 were considered to indicate statistical significance.

\section{RESULTS}

\section{Phytochemical analysis of red cabbage and broccoli extracts}

Total phenolics, total flavonoids, total antioxidant capacity and DPPH radical scavenging activities were determined in the two extracts. The results showed that the level of total phenolics in red cabbage extract was higher than that were in broccoli extracts, (red cabbage was 1.532 and broccoli was $0.986 \mathrm{mg}$ gallic acid equivalents (GAE) per $\mathrm{mL}$ of extract). Total flavonoids contents in red cabbage were $0.169 \mathrm{mg}$ quercetin equivalent $/ \mathrm{mL}$ extract, while broccoli florets extracts exhibited $0.127 \mathrm{mg}$ quercetin equivalent/ml extract. Total antioxidant capacities using phosphomolybedate method was indicated that in red cabbage was 0.155 $\mathrm{mg} / \mathrm{mL}$ and broccoli was $0.096 \mathrm{mg} / \mathrm{mL}$. The DPPH radical scavenging activity, inhibition percentage and the inhibitory concentration $50\left(\mathrm{IC}_{50}\right)$ values for the two aqueous methanolic extracts were shown in table 2 . Red cabbage leaves extracts were determined to be slightly more active in free radicals scavenging than broccoli florets extracts, the results denoted that the level of DPPH free radical scavenging activity caused by red cabbage leaves extracts was $61 \%$ and their $\mathrm{IC}_{50}$ value was $0.081 \mathrm{mg} / \mathrm{mL}$ extract. Broccoli florets extracts showed DPPH free radical scavenging activitity $51 \%$ and $\mathrm{IC}_{50}$ value for DPPH radical scavenging was 0.109 $\mathrm{mg} / \mathrm{mL}$ (table 2).

Table 2: Phytochemical parameters of red cabbage and broccoli extracts.

\begin{tabular}{lll}
\hline $\begin{array}{l}\text { Phytochemical } \\
\text { parameters }\end{array}$ & Red cabbage & Brocolli \\
\hline Phenolics $(\mathrm{mg} / \mathrm{ml})$ & $1.532 \pm 1.81$ & $0.986 \pm 2.14$ \\
Flavonoids $(\mathrm{mg} / \mathrm{ml})$ & $0.169 \pm 1.09$ & $0.127 \pm 1.91$ \\
TAC (PMA) (mg/ml) & $0.155 \pm 1.21$ & $0.096 \pm 1.54$ \\
DPPH \% & $61 \pm 2.01$ & $51 \pm 2.61$ \\
$\mathrm{IC}_{50}(\mathrm{mg} / \mathrm{ml})$ & 0.081 & 0.109 \\
\hline
\end{tabular}

\section{Effect of extracts on the viability of colorectal cancer cell line (CaCO2)}

The colon cancer cell line $(\mathrm{CaCO} 2)$ was treated with various concentrations of red cabbage leaves and broccoli florets extracts. Their anti-proliferative effects were determined based on cells' ability to metabolically reduce MTT to a formazan dye. The results revealed that brassica vegetables (red cabbage leaves and broccoli florets) extracts exhibited selective cytotoxicity in the colon cancer cell line. Broccoli extracts showed a potential cytotoxic effect with a minimum concentration killing $50 \%$ of colon cancer cell $\left(\mathrm{IC}_{50}\right) 6.64 \mu \mathrm{g} / \mathrm{mL}$ and red cabbage extracts $\mathrm{IC}_{50}$ concentration $30.04 \mu \mathrm{g} / \mathrm{mL}$ against vehicle treated control as shown in Fig. 1. Broccoli extracts showed more efficient anticancer activity against $\mathrm{CaCo} 2$ cell lines than red cabbage done. 

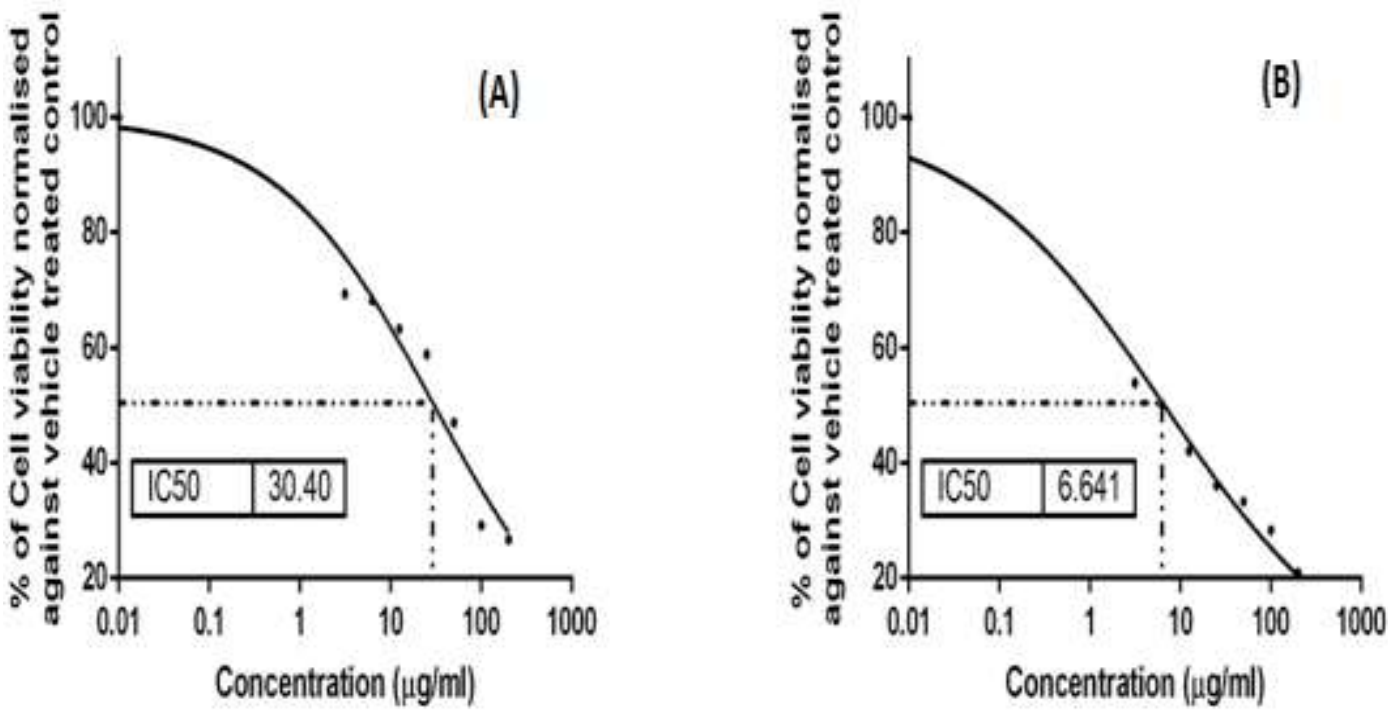

Figure 1. Effect of plants extracts on the viability of colorectal cancer cell line (CaCO2). (A): red cabbage. (B) Brocolli.

\section{Molecular analysis}

Real time PCR was used to detect the relative expression of apoptosis related genes, Bax and caspace3, and anti-apoptosis gene, Bcl2, that reflects the changes in transcription levels of these genes in $\mathrm{CaCo} 2$ cells after administration of the two extracts for $24 \mathrm{H}$. To conduct real time PCR, we first isolated total RNA from $\mathrm{CaCo} 2$ cells. The quality and concentration of the extracted RNA were assessed by Nanodrop which revealed presence of pure RNA with considerable concentrations (ranged from 845 to $1210 \mathrm{ng} / \mu \mathrm{L}$ ) (Fig. 2). The isolated RNA was reversed transcribed into cDNA which was used as a template for $\mathrm{qPCR}$. Throughout the whole real time PCR experiment, the housekeeping gene encoding GAPDH was used as an internal reference for normalization and data was expressed as mean \pm SEM $(n=3$ in triplicate in each group). The expression level of the target gene in control $\mathrm{CaCo} 2$ cells was considered the baseline.

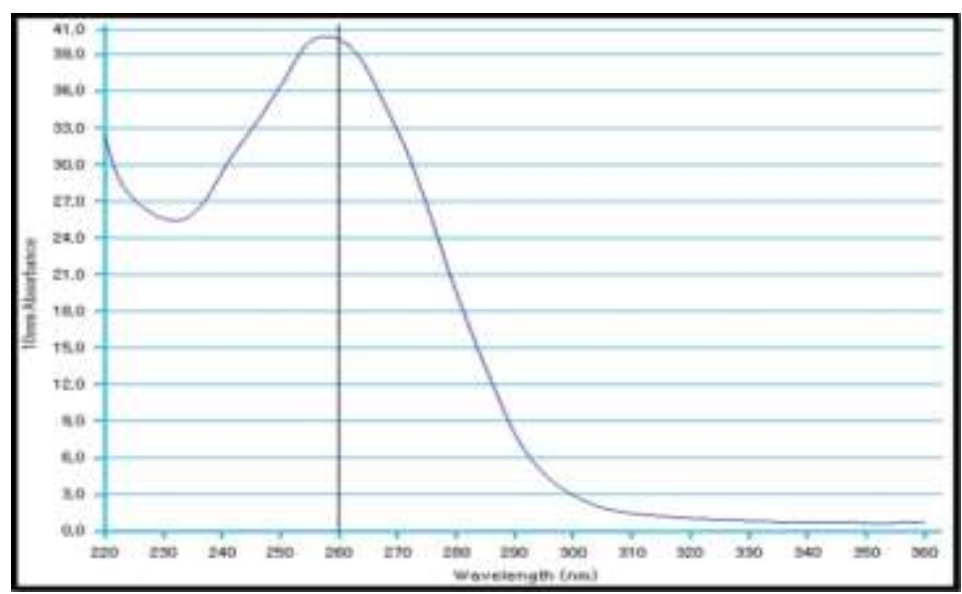

Figure 2. Nanodrop curve showing concentration and purity of extracted RNA from a representative sample which is $1010 \mathrm{ng} / \mu \mathrm{L}$. In this curve the upper top presents at 260 and the bottom at 230 which indicates the presence of pure RNA. 
Data obtained from qPCR revealed a significant $(p \leq 0.05)$ upregulation in the expression level of the apoptotic gene, $\mathrm{Bax}$, in $\mathrm{CaCo} 2$ cells following treatment of the red cabbage and broccoli extracts. Brocolli showed higher significant upregulation (5.84) than red cabbage that exhibited 3.66 fold of change. Also, the expression level of the apoptotic gene, caspase 3, was upregulated up on treatment with the broccoli and red cabbage extracts with folds of changes 9.54 and 6.32, respectively when compared with control CaCo2 cells. Downregulation in the expression level of the anti-apoptotic gene, $\mathrm{Bcl} 2$, in $\mathrm{CaCo} 2$ cells due to plants extracts exposure with lowest expression in broccoli (0.04) than red cabbage (0.07) as compared to control groups which showed fold of change 1 as shown in table 3 and Fig. 3.

Table 3: Effect of the plants extracts on the relative expression of apoptosis related gene, Bax, Caspase 3 and BCL2 in CaCo2 cells.

\begin{tabular}{llll}
\hline Cells and treatments & Fold change & \\
& Bax & Caspase 3 & Bcl2 \\
\hline $\mathrm{CaCO} 2$ cells & $1.00 \pm 0.03$ & $1.00 \pm 0.03$ & $1.00 \pm 0.02$ \\
$\mathrm{CaCO} 2+$ red cabbage extracts & $3.66 \pm 0.25$ & $6.32 \pm 0.21$ & $0.07 \pm 0.009$ \\
$\mathrm{CaCO} 2+$ Brocolli extracts & $5.84 \pm 0.37$ & $9.54 \pm 0.38$ & $0.04 \pm 0.007$ \\
\hline
\end{tabular}

* means significant change $(\mathrm{p} \geq 0.05)$.
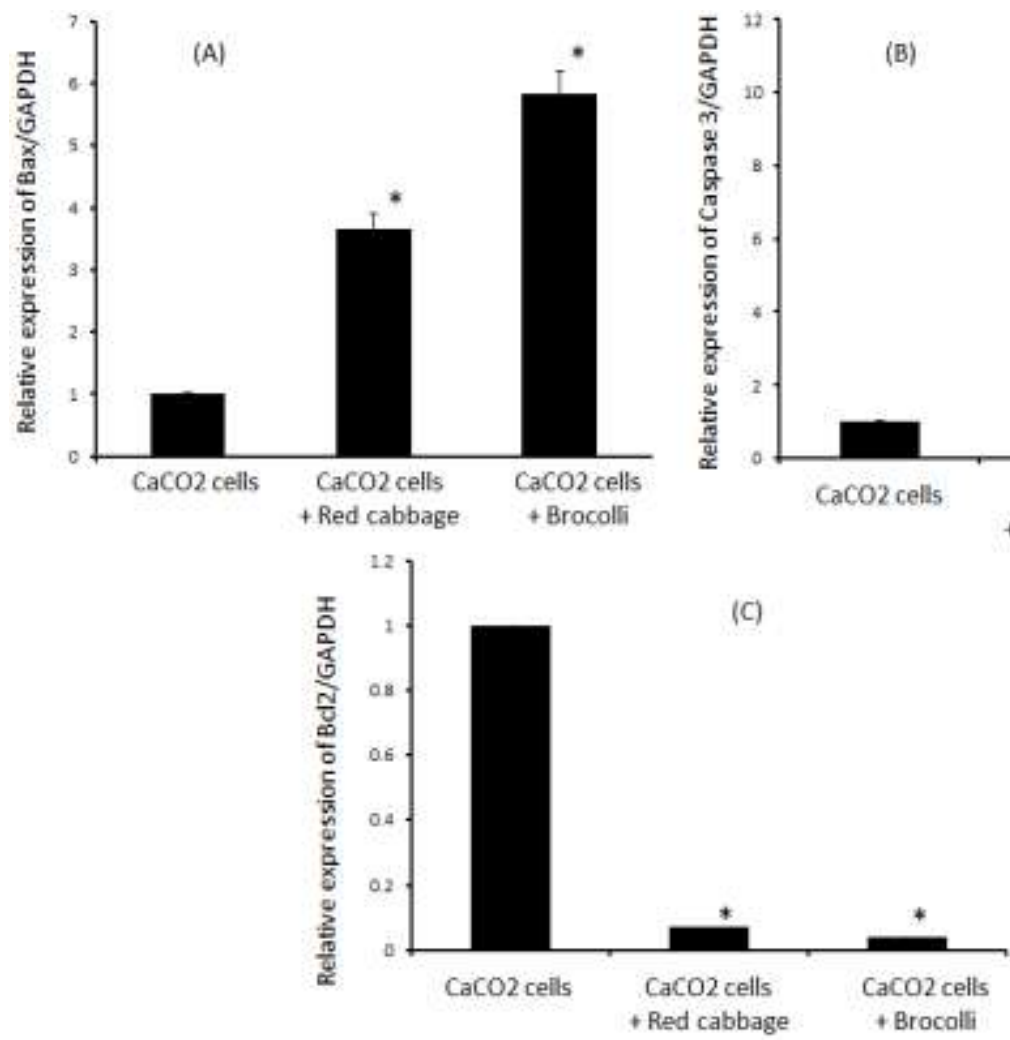

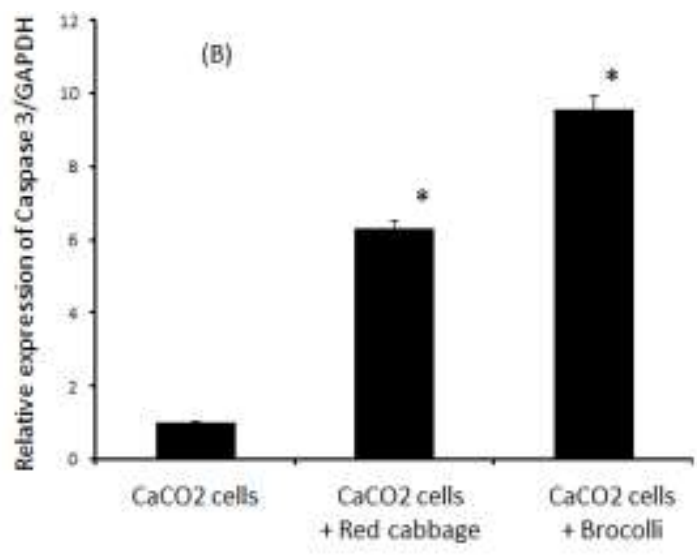

+ Brocolli

Figure 3. Graphical presentation of real-time quantitative PCR analysis of the expression of three different apoptotic related genes in $\mathrm{CaCo} 2$ cells after treatment of red cabbage and broccoli extracts. (A) Bax gene. (B) Caspase 3 gene. (C) Bcl2 gene. * means significant change $(p \geq 0.05)$. 


\section{DISCUSSION}

Plant tissues rich in antioxidants with different activities; several methods have been developed to evaluate the antioxidant activity in plant tissues $\left[{ }^{18}\right]$. The phytochemical contents including total phenolic, total flavonoid, total antioxidant capacity and free radicals scavenging activity of DPPH in red cabbage leaves and broccoli florets extracts were evaluated in this study. It has been reported that there was a strong relationship between vegetables intake with reducing certain types of cancer diseases $\left[{ }^{19}\right]$. The results of the present study are generally in agreement with other reports. It has been reported that total phenols content for red cabbage cultivated in the U. S was $254 \mathrm{mg}$ per $100 \mathrm{~g}$ fresh weight $\left[{ }^{20}\right]$, which is slightly higher than the Egyptian red cabbage in this study. Flavonoids are included flavonol, quercetin, anthocyanin and catenchin $\left[{ }^{21}\right]$; the antioxidant activities of flavonoids which are beneficial to human health by scavenging harmful radicals have been addressed in both extracts. The total flavonoids amount in the extracts was determined based on quercetin equivalent, in which red cabbage leaves has the highest flavonoids content when compared with broccoli florets. DPPH radicals are well known in the model system to evaluate the scavenging properties of numerous natural products. The examined scavenging activity against DPPH radicals of both extracts indicated different values with small variance $\left(61 \%\right.$ for red cabbage with $\mathrm{IC}_{50}$ reached $0.081 \mathrm{mg} / \mathrm{mL}$ and $51 \%$ for broccoli, its $\mathrm{IC}_{50}$ was $0.109 \mathrm{mg} / \mathrm{mL}$ ).

Cancer is a multi-factorial disease caused by multiple cell signaling aberrations. Conventional chemotherapeutic agents are generally accompanied by harmful side effects with resistance to therapy $\left[{ }^{22}\right]$. Natural products derived from plants are used as food, chemicals and herbal medicines, currently used as a promising source to cure types of cancer effectively due to their capability to promote apoptosis and/or cell cycle arrest without toxic effect in healthy cells $\left[{ }^{23}\right]$. In the present study, the in vitro cytotoxic effect of red cabbage leaves and broccoli florets extracts on colon cancer was investigated and the obtained results revealed that the inhibitory concentration that kill $50 \%$ ( $\left.\mathrm{IC}_{50}\right)$ of cells for broccoli was very low $(6.64 \mu \mathrm{g} / \mathrm{mL})$ indicating that broccoli has a powerful anticancer activity compare to red cabbage that showed $\mathrm{IC}_{50}$ equal $30.4 \mu \mathrm{g} / \mathrm{mL}$, the data obtained indicated that there were no relationship between the antioxidant activities and anticancer activities.

It has been reported that about half of all cancers express the anti-apoptotic proteins such as Bcl2. Some of digestive organs including colon appear to be highly resistant to apoptosis. The molecular mechanism of this loss of capabilities to undergo apoptosis is unknown $\left[{ }^{24,25}\right]$. In this study, the contribution of apoptosis induction up on treatment with brassica vegetables extracts in inhibiting colorectal cancer development was addressed. Gene expression analysis results by using RT-PCR of apoptotic and anti-apoptotic related genes of colon cancer cell lines treated 
with brassica (red cabbage and broccoli) extracts indicated that broccoli enhance apoptosis in colon cancer by upregulating apoptotic genes and downregulating the anti-apoptotic genes more than red cabbage. So, broccoli extracts have high anticancer activities compared with red cabbage that not related to the antioxidant properties. These could help in development of good therapeutic strategy in colon cancer treatment targeting apoptosis induction using naturally occurring vegetables without side effects and without harmful effects on normal cells. This study is agreed with Mas et al., who demonstrated that extracts from isothiocyanates-rich brassica oleracea induce apoptosis in HT-29 cells by increasing caspase 3 activities $\left[{ }^{26}\right]$.

\section{CONCLUSION}

The anticancer properties of brassica vegetables extracts (red cabbage and broccoli) not related to their antioxidant activities. As broccoli florets exhibited anticancer efficacy, inhibiting the proliferation of colon cancer cells and inducing their apoptosis more than red cabbage. Vice versa, red cabbage showed antioxidant activities more than broccoli. Brassica plants are potentially candidates for human health due to their powerful antioxidant and anticancer activities. Particularly, broccoli florets are promising source of compounds that could be beneficial for colon cancer treatment.

\section{REFERENCES}

1. Khalaj, L., Nejad, S.C., Mohammadi, M., Zadeh, S.S., Pour, M.H., Ashabi, G., et al. Assessing competence of broccoli consumption on inflammatory and antioxidant pathways in restraint-induced models: Estimation in rat hippocampus and prefrontal cortex. BioMed Res Int. 2013; 2013:1-13.

2. Huang, W.Y., Cai, Y.Z., Zhang, Y. Natural phenolic compounds from medicinal herbs and dietary plants: potential use for cancer prevention. Nutr Cancer. 2010; 62:1-20.

3. Tsao, R., 2010. Chemistry and biochemistry of dietary polyphenols. Nutrients. 2010; 2:1231-46.

4. Lambert, J.D., Hong, J., Yang, G.Y., Liao, J., Yang, C.S. Inhibition of carcinogenesis by polyphenols: evidence from laboratory investigations. Am J Clin Nutr. 2005; 81:284-291.

5. Medina, S., Dominguez-Perles, R., Moreno, D., Garcia-Viguera, C., et al. The intake of broccoli sprouts modulates the inflammatory and vascular prostanoids but not the oxidative stress-related isoprostanes in healthy humans. Food Chem. 2015; 173:11871194.

6. Uhl, M., Kassie, F., Rabot, S., Grasl-Kraupp, B., et al. Effect of common Brassica vegetables (Brussels sprouts and red cabbage) on the development of preneoplastic 
lesions induced by 2-amino-3-methylimidazol[4,5-f]quinoline (IQ) in liver and colon of Fisher 344 rats. J Chromatogr B. 2004; 802:225-230.

7. Chaudhary, A., Sharma, U., Vig, A.P., Singh, B., Arora, S. Free radical scavenging, antiproliferative activities and profiling of variations in the level of phytochemicals in different parts of broccoli (Brassica oleracea). Food Chem. 2014; 148:373-380.

8. De Lourdes Reis Giada M. Food phenolic compounds: main classes, sources and their antioxidant power. Oxidative stress and chronic degenerative diseases a role for antioxidants. In Tech. 2013; 2013:87-112.

9. Johnson, I.T. Anticarcinogenic effects of diet-related apoptosis in the colorectal mucosa. Food Chem Toxicol. 2002; 40:1171-8.

10. Ruemmele, F.M., Schwartz, S., Seidman, E.G., et al. Butyrate induced Caco-2 cell apoptosis is mediated via the mitochondrial pathway. Gut. 2003; 52:94-100.

11. Buda, A., Qualtrough, D., Jepson, M.A., et al. Butyrate downregulates alpha2beta1 integrin: a possible role in the induction of apoptosis in colorectal cancer cell lines. Gut. $2003 ; 52: 729-34$.

12. Smith, T.K., Mithen, R., Johnson, I.T. Effects of Brassica vegetable juice on the induction of apoptosis and aberrant crypt foci in rat colonic mucosal crypts in vivo. Carcinogenesis. 2003; 24:491-495.

13. Singelton, V.R., Orthifer, R., Lamuela-Raventos, R.M. Analysis of total phenols and other oxidation substrates and antioxidants by means of Folin-Ciocalteu reagent. Methods Enzymol. 1999; 299:152-178.

14. Zhishen, J., Mengcheng, T., Jianming, W. The determination of flavonoid contents in mulberry and their scavenging effects on superoxide radicals. Food Chem. 1999; 64:555-559.

15. Prieto, P., \& Pineda, M. Spectrophotometric quantitation of antioxidant capacity through the formation of a phosphomolybdenum complex: specific application to the determination of vitamin E. Anal Biochem. 1999; 269:337-341.

16. Blois, M.S. Antioxidant determinations by the use of astable free radical. Nature. 1958; 181:1199-1200.

17. Livak, K.J., \& Schmittgen, T.D. Analysis of Relative Gene Expression Data Using RealTime Quantitative PCR and the $2^{-\Delta \Delta C t}$ Method. Methods. 2001; 25:402-408.

18. Velioglu, Y.S., Mazza, G., Goal, L., Oomah, B.D. Antioxidant Activity and Total Phenolics in Selected Fruits, Vegetables, and Grain Products. J Agric Food Chem. 1998; 46:4113-4117. 
19. Wolfe, K., Wu, X., Liu, R.H. Antioxidant activity of apple peels. J Agric Food Chem. 2003; 51:609-614.

20. Wu, X., Beecher, G.R., Holden, J.M., Haytowitz, D.B., et al. Lipophilic and hydrophilic antioxidant capacities of common foods in the United States. J Agric and food Chem. 2004; 52:4026-4037.

21. Mervat, M.M., \& Hanan, A.A. Antioxidant Activities, Total Anthocyanins, Phenolics and Flavonoids Contents of Some Sweetpotato Genotypes under Stress of Different Concentrations of Sucrose and Sorbitol. Aust J Basic and App Sci. 2009; 3:3609-3616.

22. Huang, H.P., Chang, Y.C., Wu, C.H., Hung, C.N., Wang, C.J. Anthocyanin-rich mulberry extract inhibit the gastric cancer cell growth in vitro and xenograft mice by inducing signals of p38/p53 and c-jun. Food Chem. 2011; 129:1703-1709.

23. Shahneh, F.Z., Baradaran, B., Majidi, J., Babaloo, Z. Echinophora platyloba DC (Apiaceae) crude extract induces apoptosis in human prostate adenocarcinoma cells (PC-3). Biomed J. 2014; 37:298-304.

24. Amundson, S.A., Myers, T.G., Scudiero, D., et al. An informatics approach identifying markers of chemosensitivity in human cancer cell lines. Canc Res. 2000; 60:61016110.

25. Marshman, E., Ottewell, P.D., Potten, C.S., et al. Caspase activation during spontaneous and radiation-induced apoptosis in the murine intestine. J Pathol. 2001; 193:1-9.

26. Mas, S., Crescenti, A., Gassó, P., et al. Induction of apoptosis in HT-29 cells by extracts from isothiocyanates-rich varieties of Brassica oleracea. Nutr Cancer. 2007; 58:107114.

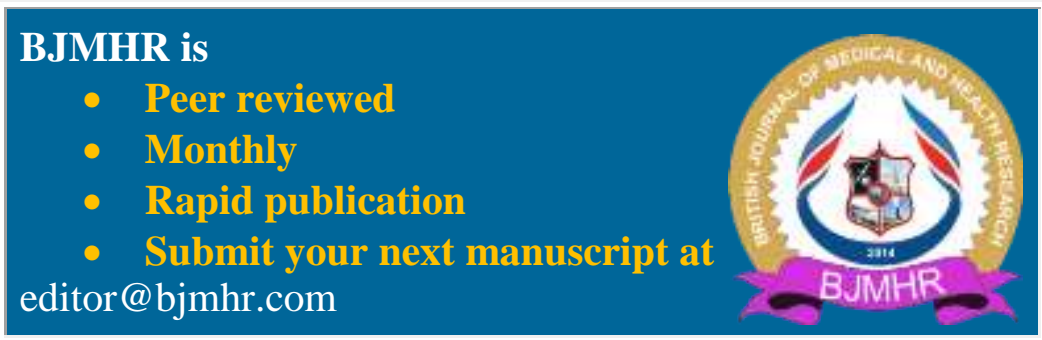

